\title{
Using hot potato game in teaching speaking to elementary school students in Regaji Village Karo Regency
}

\author{
Rudy Sofyan ${ }^{1 *}$, Parlindungan ${ }^{1}$ \\ ${ }^{1}$ Linguistics Department, Faculty of Cultural Sciences, Universitas Sumatera Utara \\ Email: rudy@usu.ac.id
}

\begin{abstract}
Speaking is the skill prioritized in teaching English to elementary school students. However, English teachers frequently encounter problems in teaching speaking or in motivating them to speak English. Therefore, teachers have to find an appropriate technique or media that can solve such a problem. One of the techniques that can be used is using games, such as the hot potato game. This paper aims at describing the use and the advantages of hot potato game in teaching speaking to elementary school students. This study used a descriptive method taking the elementary school teacher and students in Regaji Village of Karo Regency, North Sumatra, as the participants. The data were the process of teaching and learning English using the hot potato game as the technique. The data were collected using observations and interviews and were analyzed qualitatively. The results of the analysis show that using the hot potato game in teaching speaking to elementary school students provides several advantages: (i) creating a fun learning atmosphere; (ii) improving the students' motivation in learning English; (ii) generating students' competitiveness in learning English; (iii) helping students to improve their vocabulary stock; and (iv) positively changing the students' view of learning English. It is concluded that using the hot potato game is a good technique in teaching speaking English to elementary school students.
\end{abstract}

Keywords: elementary school students, hot potato game, teaching and learning English, speaking skill

\section{INTRODUCTION}

As an international language, English becomes the first language used in global business, technology, science, media, and education (Nunan, 2003; Englander, 2014; Foyewa, 2015; Rao, 2019). Due to such a dominant role of English, most Asian countries want to build and strengthen their scientific and technological developments globally by developing their learners' English proficiency (Khamkhien, 2013), including Indonesia. This is particularly intended to prepare the Indonesian young generation to compete in the global development of science and technology.

Many studies have suggested that learning a foreign language (e.g. English) should start as early as possible (Phillips, 2010; Shin, 2010; Gawi, 2012; de Bot, 2014; Yuliansyah \& Syafei, 2018; Sofyan, Sinar, Tarigan, \& Zein, 2018; Sofyan \& Tarigan, 2019) due to their cognitive development (Piaget, 1962), socio-emotional development (Hedlund \& Sternberg, 2000; Fraser, Thompson, Day, \& Macy, 2014), and physical development (Llach \& Gomez, 2007; Clark, 2014). Based on their physical development, young learners - referring to school 
children in the ages between 6 and 11 years old (Cameron, 2001; Fraser et al., 2014) - are physically very active who like playing, running, or just moving (Llach \& Gomez, 2007). Besides, they are completely ready to learn more complex skills (Clark, 2014), such as learning English skills.

In the context of education level in Indonesia, young learners are students of elementary schools. Although eliminated from the local content suggested in the latest curriculum for Indonesian elementary schools, English is reported to continue being taught as local content in many elementary schools (Iskandar, 2015; Kaltsum, 2016). Borrowing the theory of first language acquisition, where infants acquire language through listening and speaking (Clark, 2009; Rosa, 2013), oral skills should be treated as the first skills taught to young learners. Teaching speaking is given more priority in teaching English to elementary school students because the evaluation of their English proficiency is emphasized on their speaking skills.

Considering the characteristics of elementary school students, one of the methods that can make learning speaking easier and more enjoyable is learning while playing, i.e. using games. Games are popular among elementary school students because they like playing. Through games, they can interact, discover, and adapt to their surroundings (Bakhsh, 2016). The game can be a means by which students develop their skills and capabilities for effective learning. The physical activities in a game can support learners' physical development. In addition, the game can serve as the means of provoking students' emotions, especially enjoyment. McGoninal (2011) argues that a game provides an opportunity for students to focus their energy on something they are good at and enjoy.

Several studies on the use of games in teaching speaking to elementary school students or young learners have been conducted in the previous studies, such as Scattergories game (Yuliansyah \& Syafei, 2018), traditional or conventional games (Rusiana \& Nuraeningsih, 2016), guessing games (Hidayati, 2009; Syahara, 2010; Yuliani, 2017; Maqfirah, Fitriani, \& Chairina, 2018), board games (Rohdiana, 2017; Sofyan et al., 2018), and language games (Estrada \& Ortega, 2016). Those previous studies have shown how games can be used as a good technique in teaching speaking to elementary school students. Nevertheless, a teacher should be able to choose a certain game that matches the learning objectives (targeted skill) and the students' characteristics (Suryani \& Rosa, 2014), such as their ages and learning characteristics, and English level.

One of the interesting games applicable to teaching speaking is the hot potato game. It is a game intended to practice hand-eye coordination (https://www.playworks.org/gamelibrary/hot-potato/). This game is so flexible that makes it easy to be modified depending on the users' intended goal. In the context of foreign language learning, the modification of the hot potato game can be used as the technique in teaching speaking. There have been at least two previous studies discussing the use of hot potato game in teaching speaking: the study done by Sari (2017) and Arista (2018). Both of the studies focused on improving senior high school students' speaking ability. Those previous studies left the gap that can be filled in by this present study, i.e. applying the hot potato game in teaching speaking to young learners or students at elementary school. This is possibly done since hot potato is a flexible game that can be modified in such a way to meet the speaking skill needed by elementary school students.

Based on the rationale and the gap left by the previous studies, this paper aims at describing the use and advantages of the hot potato game in teaching speaking to elementary school students in Regaji Village, Karo Regency, North Sumatra. It is expected that this paper can enrich the teachers' technique in teaching speaking to elementary school students and can promote fun and enjoyable English learning at elementary schools. 
Rudy Sofyan et.al. Using hot potato game in teaching speaking to elementary school

\section{METHOD}

This is a descriptive study taking learning speaking English at an elementary school as a phenomenon. The participants were the sixth-year elementary school students living in Regaji Village of Karo Regency, North Sumatra. The data were the process of teaching and learning English using the hot potato game as the technique. The data were collected using observations and interviews. The data were analyzed qualitatively to find out the advantages of using the hot potato game in teaching speaking to elementary school students.

\section{DISCUSSION}

Before teaching speaking by using hot potato game to the sixth year elementary school students of SD Swasta in Regaji Village, several materials need to be prepared. The first one is preparing the music because playing this game needs musical accompaniment. The music should have a long duration because it must always accompany the whole session of the game. The second one is the "potato" itself. Although the potato can be replaced by another material, the "real" potato is used in this study. The choice of potato is precise because it is environmentally friendly and easy to find in this village. The third one is the number of sessions. At least, two sessions need to be prepared: modeling session and practice session.

Before playing the game, the students are given the model including the explanation of the rules of the game and how to play it. The students need to prepare as many sentences as possible describing their daily activities, such as "I get up at 5 in the morning", "I help my father in the field", "I have breakfast at 6 in the morning", I take a bath twice a day", "I go to bed at 9", and so forth. These sentences are needed when they hold the "hot potato". The students are also explained that the whole game session will be accompanied by music. Once the game starts, the music does too. At the beginning of the game, the teacher selects one of the students to be given a "hot potato". Once he holds it, he has to quickly say one sentence about his daily activity. This is the reason why every student needs to prepare several sentences before playing the game. After saying a sentence, he gives the "hot potato" to another student that also needs the same thing. The music is stopped at every third minute, and the student who holds the "hot potato" when the music is stopped will be given punishment. The same activity continues until the end of the game session. The student that has never been given punishment will become the winner and will be given a reward.

After the modeling session, the students are asked to practice the game in a group. They are divided into 3 groups, and each group consists of 10 to 11 students. In this practice session, the students are asked to prepare sentences describing their hobbies. In constructing the sentences, the teacher provides them with examples of describing hobbies, such as "I like cooking", "My hobby is playing a kite", "I love fishing", "My hobby is swimming", etc. The students are asked to imitate the way the teacher says the sentences so that they can pronounce them correctly. After that, the students are asked to modify the sentences by inserting their hobbies. Before playing the game, the students are also asked to practice their sentences until they can say them fluently. They can ask the teacher for any difficulties encountered in pronouncing the sentences.

Although the game is played in a group, the music is controlled by the teacher. This means that they have to start the game at the same time. They are given 30 minutes to play the game. This time limit is set following the number of the students in each group (10-11 students) so that it is expected that there will be only one student from each group that will become the winner. Then, they practice the game exactly in the same way they did during the modeling session. While they are playing the game, the teacher goes around the class to assist whenever needed. 
Rudy Sofyan et.al. Using hot potato game in teaching speaking to elementary school

Before ending the meeting, the teacher explains that the students can practice the hot potato game outside the classroom by focusing on different topics. For example, they can practice using fauna or flora-related ecolexicon (the term used in Tarigan \& Sofyan, 2018) in their sentences. In addition to the real experience obtained by the students from playing the hot potato game, the teacher can also reinforce that to speak English is not a difficult task because it only needs a lot of practice, or getting used to speaking English.

Based on the results of the observations, it was found that the students enjoyed learning speaking English although many of them are still not fluent in saying their sentences. All of the students look excited. While practicing speaking, they enjoy the music accompaniment. They do not realize that while playing the game, they practice speaking English. Such a practice makes them getting used to speaking in English, which is very good at building their English fluency. This is in line with Harmer (2007) arguing that if the students keep practicing English, they will be getting used to it. Also, this makes them more motivated in learning speaking English. Some studies have found that motivation is one of the key success factors in learning English (Alsayed, 2003; Oroujlou \& Vahedi, 2011; Bellés-Fortuño \& Ramírez, 2015; Alizadeh, 2016). Alsayed (2003) argues that motivation has the highest correlation with achievement in a foreign language. The results of the observations are confirmed by the results of the interviews with the students and the teacher. They say that the hot potato game makes the class exciting and interesting. All of the students participate actively in the class without being ashamed to speak English.

In addition, to make fun of learning, the hot potato game can generate the students' competitiveness in learning. Students at the elementary school age psychologically like competitiveness. As they want to become the winner, they actively participate in the game by always trying to be more and more fluent in saying their sentences. This corresponds to McGoninal's (2011) statement that games can provoke students' emotions.

Moreover, the use of the hot potato game can enrich the students' vocabulary stock. Vocabulary is the most determinant factor in speaking, without which none of the ideas can be conveyed. During the game, they will listen to sentences uttered by their classmates, and they might not know some of the words contained in those sentences. They can ask their classmates or teacher to explain the meaning of the unknown words. Therefore, this activity becomes one of the sources of vocabulary acquisition (Llach, \& Gomez, 2007). This activity certainly promotes the concept of cooperative learning where the students can improve their vocabulary through cooperation with their classmates.

Furthermore, using the hot potato game also affects the students' psychology in learning speaking English. By playing the game, they can get experience by themselves that speaking English is not difficult. One of the obstacles in learning English experienced by many students is their stereotype of English as a difficult lesson. After learning speaking by using this game, they find that English is not as scary as the one that used to exist in their mind. Hopefully, through this psychological change, they start to love learning English.

The hot potato game is easy to use as it does not have complicated rules. The students can practice the game easily once they have been exposed to game modeling. Besides, it is cheap as it requires neither expensive materials nor sophisticated technology. Especially in rural areas with their limitations in accessing sophisticated technology equipment, this game can be a good alternative.

\section{CONCLUSIONS AND SUGGESTIONS}

Based on the discussion on using the hot potato game in teaching speaking, it is concluded that the game is applicable to be used in teaching speaking English to elementary 
Rudy Sofyan et.al. Using hot potato game in teaching speaking to elementary school

school students. It is a flexible game that can be modified to be a teaching technique to any level of students. It requires a teacher's creativity to make it possible to be used at a certain level of education. In this paper, the modification is made by asking the students to make sentences describing their daily activities. The use of the hot potato game provides several advantages: (i) it makes the learning process fun and improves the students' motivation in learning English; (ii) it generates students' competitiveness in learning English; (iii) it helps students to improve their vocabulary stock; and (iv) it positively changes the students' view of learning English.

Based on the easy implementation of the hot potato game in teaching speaking English and its advantages, it is suggested to teachers at elementary schools to use it in teaching speaking. They are suggested to adapt the materials corresponding to the targeted learning objective. Although the results of observations show that the use of the hot potato game in teaching English to elementary school provides several advantages, the effect of this game also needs to be empirically tested. Therefore, other future studies are expected to explore the effect of using the hot potato game on elementary school students in speaking English.

\section{REFERENCES}

Alizadeh, M. (2016). The impact of motivation on English language learning. International Journal of Research in English Education, 1(1), 11-15.

Alsayed, M. (2003). Factors that contribute to success in learning English as a foreign language. Damascus University Journal, 19(1+2), 21-44.

Arista, J. (2018). Improving the students' speaking skill through hot potato game at the second grade of senior high school students (Unpublished Thesis). Medan: UINSU.

Bakhsh, S. A. (2016). Using games as a tool in teaching vocabulary to young learners. English Language Teaching, 9(7), 120-128.

Bellés-Fortuño, B. \& Ramírez, N. O. (2015). Motivation: A key to success in the foreign language classroom? A case study on vocational training and higher education English courses. Proceedings of the 1st International Conference on Higher Education Advances, HEAd'15, pp. 142-148.

Cameron, L. (2001). Teaching languages to young learners. Cambridge: Cambridge University Press.

Clark, D. (2014). Active play experiences help young children develop physical literacy. Retrieved on September 15, 2020, from https://activeforlife.com/active-play-developsphysical-literacy/.

Clark, E. V. (2009). First language acquisition. Cambridge: Cambridge University Press.

de Bot, K. (2014). The effectiveness of early foreign language learning in the Netherlands. Studies in Second Language Learning and Teaching, 4(3), 409-418.

Englander, K. (2014). The rise of English as the language of science. In: Writing and publishing science research papers in English: A global perspective. Dordrecht: Springer.

Estrada, L. A. \& Ortega, D. V. (2016). Teaching speaking skill through language games in a fifth grade of a public school from Pereira (Unpublished Doctoral Dissertation). Pereira: Universidad Tecnológica De Pereira.

Foyewa, R. A. (2015). English: The international language of science and technology. International Journal of English Language and Linguistics Research, 3(5), 34-41.

Fraser, M. W., Thompson, A. M., Day, S. H., \& Macy, R. J. (2014). The making choices program: Impact of socio-emotional skills training on the risk status of third graders. The Elementary School Journal, 114(3), 354-379. 
Rudy Sofyan et.al. Using hot potato game in teaching speaking to elementary school

Gawi, E. M. K. (2012). The effects of age factor on learning English: A case study of learning English in Saudi Schools, Saudi Arabia. English Language Teaching, 5(1), 127-139.

Harmer, J. (2007). How to teach English: An introduction to the practice of English language teaching (2nd Edition). London: Longman.

Hedlund, J. \& Sternberg, R. J. (2000). Too many intelligence? Integrating social, emotional, and practical intelligence. In R. Bar-On \& J. Parker (Eds), The handbook of emotional intelligence: Theory, development, assessment, and application at home, school, and in the workplace (pp. 136-167). San Francisco, CA: Jossey-Bass Inc.

Hidayati, D. R. N. (2009). Teaching English for young learners by using "guessing” games in students' speaking skill (Unpublished Thesis). Semarang: Universitas Negeri Semarang.

Iskandar, I. (2015). Putting English as a local content subject in primary schools: Teachers' belief and its impact on their teaching delivery. Proceedings of the 62nd TEFLIN International Conference, pp. 1-10.

Kaltsum, H. U. (2016). Bahasa Inggris dalam Kurikulum 2013 di sekolah dasar. Proceedings of the 3rd University Research Colloquium, pp. 276-283.

Khamkhien, A. (2013). Roles of English as an international language on learning strategies among Japanese and Thai learners. Journal of Teaching and Education, 2(2), 473-483.

Llach, P. A. \& Gomez, A. B. (2007). Children's characteristics in vocabulary acquisition and use in the written production. RESLA, 20, 9-26.

Maqfirah, Y., Fitriani, S. S., \& Chairina. (2018). The use of guessing games to teach speaking skill. Research in English and Education (READ), 3(1), 91-99.

McGonigal, J. (2011). Reality is broken: Why games make us better and how they can change the world. New York: The Penguin Press.

Nunan, D. (2003). The impact of English as a global language on educational policies and practices in the Asia-pacific region. TESOL Quarterly, 37(4), 589-613.

Oroujlou, N. \& Vahedi, M. (2011). Motivation, attitude, and language learning. Procedia Social and Behavioral Sciences, 29(2011), 994-1000.

Phillips, S. (2010). Young learners. Oxford: Oxford University Press.

Rao, P. S. (2019). The role of English as a global language. Research Journal of English (RJOE), 4(1), 65-79.

Rohdiana, A. (2017). Developing communicative board game in speaking descriptive text to EFL young learners. Proceedings of The 2nd TEYLIN International Conference. pp. 4958.

Rosa, R. N. (2013). Introduction to linguistics. Padang: Sukabina Press.

Rusiana, R. \& Nuraeningsih, N. (2016). Teaching English to young learners through traditional games. LANGUAGE CIRCLE: Journal of Language and Literature, X(2), 193-200.

Sari, K. (2017). Using hot potato technique to teach extensive speaking skills at the second grade students of Senior High School 3 Takalar (Unpublished Thesis). Makassar: UIN Alauddin Makassar.

Shin, S. J. (2010). Teaching English language learners: Recommendations for early childhood educators. Dimensions of Early Childhood, 38(2), 13-21.

Sofyan, R., Sinar, T. S., Tarigan, B., \& Zein, T. T. (2018). Using a "snake and ladder" game in teaching speaking to young learners. ABDIMAS TALENTA, 3(2), 226-231.

Sofyan, R. \& Tarigan, B. (2019). Building literacy awareness through a community library. ABDIMAS TALENTA: Jurnal Pengabdian Kepada Masyarakat, 4(2), 295-301.

Suryani, A. \& Rosa, R. N. (2014). Using a board game "snake and ladder" in teaching speaking at junior high school. Journal of English Language Teaching, 2(2), 16-24. 
Rudy Sofyan et.al. Using hot potato game in teaching speaking to elementary school

Syahara, F. R. (2010). Improving students' speaking skill by using guessing game to the fifth grade of SD N 04 Kemiri Karanganyar (Unpublished Thesis). Solo: Universitas Sebelas Maret.

Tarigan, B. \& Sofyan, R. (2018). Maintaining Karonese ecolexicon through traditional game cengkah-cengkah. International Journal of Applied Linguistics and English Literature, 7(4), 177-183.

Yuliani, S. (2017). Teaching English vocabulary by using guessing game to the fifth grade students 117 Palembang. English Community Journal, 1(2), 123-129.

Yuliansyah, R. \& Syafei, A. F. R. (2018). Using Scattergories game in teaching vocabulary to elementary school students. Journal of English Language Teaching, 7(4), 595-603.

\section{ONLINE SOURCES}

Hot Potato, retrieved on September $21^{\text {st }} 2020$ from https://www.playworks.org/gamelibrary/hot-potato/. 